\title{
Boom Time - Revisiting Capital and Labour in the Copperbelt
}

\section{Introduction}

The post-World War Two heyday of social scientific research on the Central African Copperbelt was shaped by a sustained period of global economic growth, the 'long boom'. This enabled a steady growth in copper production and company profits and, to a lesser extent, mine employment, living standards and the wider manifestations of urbanisation identified by policy-makers and academics. ${ }^{1}$ Politically, the long boom both resulted from and enabled a period of unprecedented co-operation between global capital, nation-states and organised labour, which sought to prevent or manage capitalism's propensity for economic crises, ensure effective governmental support for economic 'development' and more fairly distribute the benefits of growth between companies, workers and wider society. Variations of this 'tripartite' or Keynesian model of economic co-operation, with its origins in World War Two but applied in overcoming post-war austerity and combating the ills of poverty and backwardness, were implemented across the world until the mid-1970s, a 'win-win' policy wherein wages, profits and tax revenue could supposedly all rise simultaneously.

In late colonial and post-colonial sub-Saharan Africa, such cooperation took the form of development planning, a set of policies rooted in the assumed desirability of following a Western path, through stages that 'developing' economies could take to achieve 'take-off' towards advanced industrialisation. This influential approach disregarded the fact that no Western economy had developed in this way and that the distinct inter-linked imperial histories of Western and

1 For the history of the global 'long boom' and the subsequent long downturn, see Robert Brenner, The Economics of Global Turbulence (London: Verso, 2006). 
African economies meant that they started from very different places. $^{2}$ Contemporaneous analysts of the Copperbelt nonetheless extrapolated from the region's soaring economic growth and output to suggest that it was developing a Western-style industrial economy and society. Today, after nearly three decades of economic stagnation and decline, the Copperbelt's long boom is recalled nostalgically as a golden age of growth, development and shaped prosperity. As this chapter will show, both the optimistic vision and the fond memory are significantly at odds with the region's actual, highly uneven socio-economic development during the 'long boom', a period in which copper mining failed to stimulate a self-sustaining industrial economy comparable with those of the West.

There are many reasons why the Copperbelt's own long boom did not provide the basis for fully fledged regional or national industrialisation. The failure of Zambia's mining industry to spark sustained national development has been the subject of sustained analysis: while some claim that state interference and political manipulation undermined the industry's competitiveness, others argue that a coherent industrial policy could have overcome mineral dependency. ${ }^{3}$ While these explanations help us understand the failures of postindependence economic development, both downplay the structural difficulties of transforming a mining industry created in the interests of Western-controlled global markets, in which the colonial extraction of raw or semi-processed minerals was designed to serve already established metropolitan industrial economies. What matters for this study is that, even during the period of the Copperbelt's now fondly remembered golden age, the inability of copper and cobalt mining to provide the basis for large-scale formal employment and self-sustaining

2 Cooper and Packard (eds.), International Development and the Social Sciences; Michael Jennings, 'Building Better People: Modernity and Utopia in Late Colonial Tanganyika', Journal of Eastern African Studies 3, 1 (2009), pp. 94-111.

3 For the former, see Christopher S. Adam and Antony M. Simpasa, 'The Economics of the Copper Price Boom in Zambia', in Fraser and Larmer, Zambia, Mining and Neo-Liberalism, pp. 59-90. See also Christopher Adam, Paul Collier and Michael Gondwe (eds.), Zambia: Building Prosperity from Resource Wealth (Oxford: Oxford University Press, 2014). For the latter, see Gabriel Pollen, 'From total factor productivity to structural change: interrogating economic growth and structural transformation from a developing country perspective with reference to Zambia', unpublished $\mathrm{PhD}$ thesis, School of Oriental and African Studies (2018). 
economic development was already evident to many state and company observers.

This chapter provides a brief history of the Copperbelt's supposed 'long boom', emphasising the precarity of its actual development and showing that contemporary policy-makers stressed the inability of mining to stimulate the wider economy. ${ }^{4}$ The post-World War Two mining industry did not itself create substantial new jobs and, during the downturn of the late 1950s, growing unemployment was a major concern for governments and mine companies alike. The need to increase productivity was explained in characteristically modernist terms, with workers blamed for their insufficiently evolved understanding of the work regime. While UMHK sought to improve its workforce by the application of 'scientific' knowledge, it was only in the late 1950s that Northern Rhodesia's companies systematically invested in educating and training their African workforce. Following political independence, Zambia and Congo both saw their mining industries as vehicles for national development, but the constraints of a (post-) colonially connected mining industry undermined their governments' attempts to do so.

This chapter also explores the profoundly uneven nature of urban employment, showing that the high living standards stereotypically attributed to Copperbelt communities were in fact the preserve of an unrepresentative group of skilled African mineworkers who were, as we have seen, the disproportionate focus of policy and academic attention. As interviewees reveal, most mineworkers, and the overwhelming majority of Copperbelt residents, scraped a precarious living through low-paid work and informal trading. The emphasis on a Westernised model of urban formal growth and employment concealed the region's dependence on extraction - from the land certainly, but also from the wider 'urban' economy that was beyond the immediate purview of the mine, but dependent on it. The booming Copperbelt economy, often represented and recalled as a shared story of success, rested, in fact, on a highly stratified system of profound inequality and precarity. It is today more clearly understood that in capitalist economies in general and 'peripheral' economies in particular, formal employment was

4 This chapter draws on arguments and material first developed in my article 'Permanent Precarity: Capital and Labour in the Central African Copperbelt', published in Labor History, 58, 2 (2017), pp. 170-84. I am grateful to the journal's editors for permitting the reproduction of material here. 
never the norm and that various forms of 'informal' or 'precarious' labour were and remain as central to the functioning of these economies as 'advanced' wage labour. ${ }^{5}$ In historicising the representation of capital and labour in late colonial and early post-colonial Africa, it is clear that a range of actors - states, multi-national companies, trade unions, the International Labour Organisation (ILO) and social scientific analysts - saw wage labour as a key signifier of capitalist modernisation, yet refused to recognise 'unemployed' Africans (many of whom were, in fact, 'informally' employed) as legitimate urban residents.

\section{A Late Colonial Economic Boom: Growth Without Development}

There is no doubt that the Copperbelt experienced profound economic expansion and demographic change in the post-World War Two period. Fuelled by global economic expansion, UMHK copper production, for example, doubled, from 150,840 tonnes in 1947 and 247,000 tonnes in 1956 to 302,300 tonnes in $1960 .{ }^{6}$ Cobalt production also rose considerably. ${ }^{7}$ Mineral production made a huge contribution to the soaring value of Congolese exports, which rose from BFr 10 billion in 1948 to BFr 27 billion in $1956 .^{8}$ In Northern Rhodesia, where 268,551 tonnes of copper were produced in 1941, production rose to 700,000 tonnes by independence in 1964. The African workforce of Northern Rhodesia's mines numbered 26,023 in 1940, rising to 37,237 by 1954 and 38,465 by $1961 .^{9}$ The workforce of UMHK was more stable: having employed 16,300 workers as early as 1930 , the company's training polices enabled it to achieve greater output with a similar number of workers - in 1952 it employed 19,008 African

5 Nick Bernards, 'Placing African Labour in Global Capitalism: The Politics of Irregular Work', Review of African Political Economy, 46, 160 (2019), pp. 294-303. For an interesting recent attempt to classify informal labour in these circumstances, see Shahram Azhar and Danish Khan, 'Rethinking Informal Labor in Peripheral Capitalism: The Dynamics of Surplus, Market, and Spatiality', Labor History, 61, 3-4 (2020), pp. 320-34.

6 Dibwe dia Mwembu, Bana Shaba, p. 15.

7 Dibwe dia Mwembu, Histoire des Conditions de Vie, p. 48.

8 Dibwe dia Mwembu, Histoire des Conditions de Vie, pp. 55-6.

9 ZCCM-IH Archives (hereafter ZCCM-IH), 16.3.7A, 'African Labour Recruiting and Unemployment, Labour Exchanges, Oct 1960-Dec 1980', Central African Federation Study Group on Unemployment, 1961, p. 4. 
workers, a figure that rose to 23,312 in $1958 .^{10}$ The wider population grew much quicker: Northern Rhodesia's urban Copperbelt population tripled between 1946 and 1956, with some towns such as Bancroft (Chililabombwe) created from scratch. ${ }^{11}$

This rapid growth fuelled the representation of the Copperbelt as a region experiencing the transformation of African bush into Westernstyle towns, understood as an intensified and accelerated version of the Industrial Revolution. In 1941 RLI researcher Godfrey Wilson suggested that the growth of Northern Rhodesian mine towns such as Broken Hill (Kabwe) heralded a more balanced global economy

within the next generation ... in which ... more emphasis will inevitably be laid on secondary industry, on agriculture and on consumption; wages will inevitably rise all round - in Africa as elsewhere - industrial workers will, as often as not, be skilled supervisors of machinery; the world will need all the skill it can get; ... and the rivalry between skilled European and about-to-be skilled African will be at an end. ${ }^{12}$

Mine company publicity, for example the propaganda films produced by UMHK, conveyed the message that the Copperbelt was adopting Western-style modern industrial infrastructure, housing and societal norms and contrasted this to images of African rural poverty. ${ }^{13}$ The disproportionate attention given to 'advanced' workers by social scientists (Chapter 1) reinforced the idea that Copperbelt employees were rapidly achieving the employment and consumption patterns of their Western counterparts.

There were, however, many reasons why economic and demographic growth did not easily translate into Western-style industrialisation and development. The Copperbelt had been conceptualised from the start as a colonised region that would supply raw materials to the West's industrial heartlands, not itself become a region of industrial growth. While the post-World War Two period did see expansion in the local processing of copper ore, with refineries and smelters adding value by enabling the production of finished copper, this continued to be

10 UMHKA, 658, UMHK MOI Annual Report 1958, p. 64.

11 National Archives of Zambia (hereafter NAZ), WP 1/2/64, Special Commissioner for Western Province, Reports on Copperbelt, 1959-60, draft report on 'Municipalities and Towns', p. 1.

12 Wilson, Economics of Detribalization, pp. 29-30.

13 UMHK film, 'En Cinquante Ans' (1956): www.youtube.com/watch?v=9z4Gty CvlCg (accessed 7 May 2020). 
exported for use in products manufactured elsewhere. While conceptualisations of the Copperbelt as 'remote' are problematic in their reproduction of a Western-centred perspective, the region was indeed remote from its key markets, linked to them by a transport network controlled by colonial investors and states. As Parpart notes: '[m]ining equipment was usually purchased abroad; the skilled European labor force spent much of their large salaries on expensive imported goods; and transportation difficulties and poor land limited economic opportunities outside the line of rail'. ${ }^{14}$ The region's economy was a machine designed to transfer wealth from colony to metropole. Revenue flowed to mine companies based in Johannesburg, Brussels, London and later Salisbury, which mainly paid tax and royalties in those places. In 1938, 60 per cent of the tax levy on the Northern Rhodesian mining industry went to either the UK government or the British South Africa Company. ${ }^{15}$ Bézy noted that, despite Congo's growth, capital $-£ 60 \mathrm{~m}$ between 1948 and 1951 - was continually exported as dividend payments to the large companies (UMHK uppermost) that dominated the economy. ${ }^{16}$ The low taxes paid by mine companies meant that much of the increase in local developmental spending was financed by borrowing: Congolese government debt quintupled during the 1950s. ${ }^{17}$

After World War Two, consistent with the developmental turn, efforts were made to strengthen urban infrastructure and - in Haut-Katanga in particular - to stimulate secondary industry. By the mid-1950s Elisabethville was home to a wide range of manufacturing industries: cement, brickmaking, metal and carpentry, textiles, explosives and tobacco, as well as food and beverages. While officials were characteristically positive about these developments, they recognised that these goods were consumed by the mining industry, its workers and the wider community that depended on them. ${ }^{18}$ Late colonial policy, while seeking to expand urban economic and employment opportunities, equally wished to prevent accelerated migration from rural areas to the

14 Parpart, Labour and Capital, p. 25.

15 Official figures, cited in Heisler, 'Creation of a Stabilized Urban Society', p. 137.

16 Fernand Bézy, 'Belgian Congo 1951-52', Civilisations, 3, 2 (1953), pp. 293-7.

17 Jean-Philippe Peemans, 'The Social and Economic Development of Zaire Since Independence: An Historical Outline', African Affairs, 74, 295 (1975), pp. 148-79, p. 153.

18 Belgium Archives Africaines (hereafter BAA), 34 (6), Katanga Provincial Council (hereafter KPC) papers, Situation Politique et Administrative, March 1955, p. 11. 
towns. Across the Copperbelt there was continuing anxiety that, as missionaries and colonial officials had argued during the interwar period, the loss of productive (male) labour to urban areas would undermine rural societies. As discussed earlier, a key question for CEPSI researchers was whether African society could withstand the dislocating effects of rapid urbanisation. Doucy and Feldheim illustrated the dilemma of ensuring economic development in this context:

So on the one hand we are faced with an exodus of the indigenes to noncustomary environments, with all the dangers ... all the difficulties that this exodus contains in itself.... On the other hand, it is absolutely necessary to provide the labour to European companies because it is on this last resort that the prosperity of the colony depends on. ${ }^{19}$

There was, however, a powerful belief, in Belgian Congo at least, that development planning could overcome these problems. The pioneering Plan Décennal, adopted in 1950, set ambitious goals for higher African living standards and industrial output. By the early 1950s demand for workers in the capital Léopoldville and elsewhere soared, so that by 1952 more than one million workers were employed in Congo's towns. ${ }^{20}$ The number of workers in Katanga rose from 108,111 in 1945 to 144,184 in 1950 and 178,664 in 1954, with virtually all this increase taking place outside the mining industry. The population of the non-mine areas of Katanga's towns was, however, rising faster, from 242,537 in 1945 to 368,535 in 1950 and 509,327 in 1954 - so that a much larger urban population was dependent on the relatively modest growth in waged employment. ${ }^{21}$

Efforts were made to accelerate the growth of an indigenous middleclass Christian elite that, again following Western ideals, would stabilise urban society and act as a buffer against the influence of radical politics and religious extremism. ${ }^{22}$ In his annual report to the Provincial Council

19 Doucy and Feldheim, Problèmes du Travail, p. 12.

20 Government of Belgian Congo, Plan Décennal du Congo Belge (Brussels: Government of Belgian Congo, 1949); Leigh Gardner, 'The Fiscal History of the Belgian Congo in Comparative Perspective', in Frans Buelens and

Ewout Frankema (eds.), Colonial Exploitation and Economic Development:

The Belgian Congo and the Netherlands Indies Compared (London: Routledge, 2013), pp. 130-52.

21 BAA, 34(6), KPC, Situation Politique et Administrative, March 1955.

22 Michael O. West, The Rise of an African Middle Class: Colonial Zimbabwe, 1898-1965 (Bloomington: Indiana University Press, 2002); Phyllis Martin, Leisure and Society in Colonial Brazzaville (New York: Cambridge University 
meeting in 1955, outgoing Katangese governor René Wauthion declared: 'A major factor in the stabilisation of these centres [CECs] lies in the presence of houseowners, of shops, restaurants, workshops etc. which constitute the embryo of a middle class that is, by definition, the enemy of adventure and disorder. ${ }^{23}$ As so often however, the idealised vision of African society clashed with the practical difficulty of securing the right type of advanced African. Of the 5,656 enterprises operating in Katanga in 1954, 2,764 - roughly half - were run by Congolese. ${ }^{24}$ The other half were run by European settlers, the number of whom tripled in post-World War Two Katanga, reaching 35,507 in $1958 .{ }^{25}$ The authorities were convinced that African-run businesses would struggle because of 'the general rudimentary training of many founders of indigenous crafts or industrial enterprises in our large CECs'. ${ }^{26}$ As noted in Chapter 1, a survey of indigenous business published by CEPSI in 1955 sought to analyse not African entrepreneurs' own experiences but instead their contact with European traders, who, it was assumed, they were imitating, for the following reasons:

The modern monetary economy into which we have plunged the Black without the transition that was experienced by generations of Europeans has provoked, among those living in the cities, a rupture with their clan links and a distortion of their customary rules.... one can consider trade a new technique for the Bantu, a technique for which they do not have a reference system.... The presence of commerce for the indigenes by the Europeans ... has favoured contacts between Europeans and Africans. The latter are very likely inspired by their methods. The survey will show how well these methods have been adopted and how they have been assimilated. ${ }^{27}$

By 1957, African members of the Provincial Council were requesting that European traders were banned from retail in the CECs, so as to open up opportunities for Africans. However, few African entrepreneurs had

Press, 1995); and Laura Fair, Pastimes and Politics: Culture, Community and Identity in Post-Abolition Zanzibar, 1890-1945 (Oxford: James Currey, 2001). BAA, 34(6), KPC, Situation Politique et Administrative, March 1955, p. 1.

24 BAA, 34(6), KPC, Situation Politique et Administrative, March 1955, np.

25 Dibwe dia Mwembu, Histoire des Conditions de Vie, p. 48.

26 BAA, 35(1), KPC, Allocution D’Ouverture, 7 March 1956, p. 10.

27 Anon, 'Le Commerce Indigène au CEC d'Elisabethville', CEPSI Bulletin, 28 (1955), pp. xli-lxxv. 
access to sufficient capital or credit to run businesses such as petrol stations. $^{28}$

Indigenous commercial agriculture was a major focus of post-World War Two development planning across colonial Africa, consistent with 'take-off' models in which surplus generated by agriculture was then invested in nascent industry. ${ }^{29}$ As early as 1932, Katangese authorities had identified peri-urban areas near Elisabethville in which to encourage indigenous commercial agriculture. ${ }^{30}$ After 1945 , the expanded Institut National pour L'Étude Agronomique du Congo Belge (INÉAC) promoted scientific agriculture, with European experts charged with raising the living standards and knowledge of indigenous farmers. The Institut established a peri-urban development project in Kipopo that included a fishery. It also ran an experimental station at nearby Keyberg, seeking to overcome both Katanga's poor soil and its supposed degradation by indigenous farming methods:

The ancestral modes of agriculture were essentially and only needed to meet the strictly limited needs of subsistence. ... These conditions led the Bantu people to cultivate the land without worrying about the state in which they left it. As a result, they quickly and irreparably destroyed the productive potential of their lands. ${ }^{31}$

The multiple aims of these initiatives were, according to a 1956 CEPSI journal article by Governor Wauthion, the promotion of an indigenous middle class of commercial farmers, traders and artisans; improving the fresh food supply to Katanga's towns; and reducing the urban population by attracting city residents to these communities. Wauthion criticised previous efforts to promote commercial African agriculture, which were 'never strong enough to disengage the indigenous population from its primitive methods of work, so that they remained practically frozen in a subsistence economy'. ${ }^{32}$ The developmental projects of CEPSI in peri-urban areas near Elisabethville and Jadotville also faced familiar problems of low population density and poor soils, but also the

28 BAA, 35(4), KPC, Deuxième Séance, 21 March 1957.

29 Rostow, The Stages of Economic Growth.

30 BAA, 37(1), KPC, Session Extraordinaire, 1959, Allocution D’Ouverture du Commissaire Provincial M. Thilmany.

31 Institut National pour L'Étude Agronomique du Congo Belge (hereafter INÉAC), NILCO, 10045, report on soil conservation and fertiliser, n.d. but late 1950s.

32 Wauthion, 'Pour le Développement d'une Économie Rurale'. 
continued, if diminished, authority of chiefs over land use and allocation, which supposedly prevented its effective commercial utilisation. ${ }^{33}$ By 1955, CEPSI was co-ordinating government-funded programmes worth BFr35m in Katangese peri-urban communities. ${ }^{34}$ These efforts were complemented by UMHK's funding of health centres to make these areas desirable for retired workers and their families to relocate at the end of their working lives 'and to avoid in this way an increasing growth of the urban centres'. ${ }^{35}$ When such efforts failed to stem the tide of migration to town or to increase agricultural productivity, that failure could always be blamed on Congolese farmers' alleged lack of an enterprising mentality.

At least Belgian Congo had a plan for economic development. Northern Rhodesia's rural areas had historically been labour-sending areas: first to Katanga and then to its own mines, as well as to South Africa and Southern Rhodesia. Agricultural development in the Copperbelt, with its poor soil and low rural population, was a particularly low priority. ${ }^{36}$ Northern Rhodesia's integration into the Central African Federation in 1953 handed considerable political power to Southern Rhodesia's white commercial farmers, to whom state farming subsidies increasingly flowed and whose economic position rested on the marginalisation of their African counterparts. Retail opportunities for Africans were similarly limited by European domination and the predisposition of urban Africans for consumer goods:

There is a growing tendency for Africans to buy high priced goods, and it is the large European store rather than the small African trader who benefits from the prosperity of the Urban community. Few African traders seem to have any real business acumen. The large numbers of hawkers and pedlars, most of whom live in the African township, can no longer make a living because most Local Authorities are insisting that trading is done in recognised shops and markets. ${ }^{37}$

While official concern was expressed about rural-urban migration and the general failure of non-mining economic activities, no-one in power

33 Ibid., p. 9.

34 BAA, 35(1), KPC, Allocution d'Ouverture, 7 March 1956, p. 11.

35 UMHKA, 632, Annual Report 1956, p. 29; see also UMHKA, 631, Annual Report 1955.

36 ZCCM-IH, Copperbelt Development Plan, 1965, p. 1.29.

37 NAZ, WP 1/2/43, African Affairs Annual Report, Luanshya, 1957-60, Western Province African Affairs Annual Report, 1959, p. 10. 
seriously thought of Northern Rhodesia as a proto-national economy, or intervened to alleviate the territory's overwhelming economic dependency on Copperbelt mining.

\section{The Changing Nature of Mine Labour: Creating the Ideal Worker}

One of the major advantages of Copperbelt mines, relative to its global competitors, had always been cheap African labour, enabled by a colonial regime and the labour recruitment practices it facilitated. Mine companies across southern Africa established and/or employed recruitment agencies with preferential access to rural communities that needed to earn cash wages to pay colonial taxes. Labour initially took migrant form because unskilled men could be easily replaced and because African urban settlement was politically undesirable. Single African male mineworkers housed in temporary work camps and employed on short-term contracts were paid wages far below subsistence level, with housing and food ('rations') provided.

In Haut-Katanga, where industrial mining started in the 1910s, this approach changed at an early stage. From 1919, when the defeat of a European strike led to a shortage of skilled labour, UMHK gradually trained Africans to replace them. ${ }^{38}$ Once Africans were trained, it became useful to retain them for longer periods, to provide them with housing and services and to allow them to resettle their families - or find new ones - in town. The company's stabilisation policies meant the costs of employing African labour - while still lower than European workers - rose considerably. From the late 1930s, UMHK sought to reduce the number of African employees, seeking ongoing profitability via higher productivity. These efforts were accelerated by post-World War Two Belgian intervention: the governmental Commission Provincial pour le Travail et le Progrès des Indigènes (TEPSI) regulated not only salaries but also the provision of food and housing for workers and their families.

In sharp contrast, Northern Rhodesian mineworkers retained their essentially migrant status until the mid-to-late 1940s: although many thousands were skilled and experienced workers who moved from one

38 Higginson, A Working-Class in the Making; Perrings, Black Mineworkers in Central Africa. 
short-term contract to another in a circulatory migration pattern, their skills went unrewarded and they were legally prevented from permanent settlement. This changed with the advent of stabilisation, as Heisler notes: 'On the Copperbelt between 1948 and 1951 the number of African miners who lived with their wives in the towns owned by the mining companies increased by one half. ${ }^{39}$ Northern Rhodesian mine companies took longer to come around to the idea of a stabilised and skilful African labour force, and did so arguably only because metropolitan political pressure forced them to do so and because mineworkers secured better salaries and conditions by industrial combination and action (see Chapter 4).

In both cases, however, the cost of employing an increasingly skilled African labour force, living permanently in Copperbelt towns with their immediate families, had risen substantially by the early 1950s. It was then necessary to ensure that labour force was as productive as possible, something that companies sought to achieve by the production and application of knowledge. In Haut-Katanga, the UMHK's investment in copper processing and workforce training meant that, between 1942 and 1958, productivity grew four-fold while the number of mineworkers remained stable. ${ }^{40}$ The company justified its productivity demands by the privileged treatment it supposedly afforded its workers, as its 1952 annual report made clear:

the local labour force is expensive; every improvement in the provision of necessities for natives should therefore in the future be directly linked to an improvement in yield. In this regard, the workforce of our company finds itself clearly privileged, because by virtue of our traditional policy of improving the standard of living of our workers, we put at their disposal and that of their children, a whole system of education which will enable them to progressively access more and more qualified trades. ${ }^{41}$

The growing efficiency of UMHK was not mirrored in the wider economic development of Katanga and certainly not Congo, as the Provincial Council warned in 1957: 'The productivity of our industries needs to be improved. It is necessary that the secondary industries work

39 Heisler, 'Creation of a Stabilized Urban Society', p. 143.

40 Jean-Luc Vellut, 'Mining in the Belgian Congo', in David Birmingham and Phyllis M. Martin (eds.), History of Central Africa Vol. II (Longman, London, 1983), pp. 126-62, p. 139.

41 UMHKA, 265, UMHK Services d'Afrique, Report on Activities, 1952, p. 15. 
at full capacity and supply more and more exclusively the local market, at competitive prices'. ${ }^{42}$

In Northern Rhodesia, the sudden rise in African labour costs necessitated drastic action to improve productivity. In 1956 a report for AAC's Rhokana mine claimed that, consistent with UMHK's achievement, major increases in productivity could halve African mine employment. Its author, W. T. de Villiers, argued:

In the early days and even up to 1950 the wages of the African worker were very low. The African worker was and still is to a major extent regarded as 'black electricity', there for abundant use ... The productivity of African labour as used in the Mining Industry is extremely low.... the African still works at his own tempo ... Many supervisors of Africans still have the conception that African labour is cheap, inefficient and is only to be used on simple operations. ${ }^{43}$

De Villiers found that, while production by the mine's c.10,000 African workers had increased from 82,877 tons in $1944 / 45$ to 92,033 tons in 1955/56, the cost per individual African shift worked had risen from $£ 25 s$ in 1945 to more than $£ 15$ in 1956 . If rising costs were not offset by increased productivity, current profits of $£ 84.2$ per ton would fall to $£ 27$ per ton by $1960 / 61$. The average length of service of each worker, which had risen from 3.42 years in 1954 to 4.48 years in 1956, needed to be significantly extended (by 1956, 39.6 per cent of UMHK workers had already worked for twelve years or more). ${ }^{44}$ De Villiers recommended the recruitment of more married workers to encourage stabilisation and incentivise long service, while 'higher standard' European personnel would need to make better use of and have better relations with African workers.

For this to be achieved, however, the divorcing of African workers from their rural societies needed to be accelerated. Although it had until recently been company policy to resist urban stabilisation, De

42 BAA, 35(7), KPC, Deuxième Session, Séance Pleniere et Vœux,

2 September 1957, p. 4.

43 ZCCM-IH, 3.8.1C, Utilisation of African Labour Report 1957, W. T. de Villiers, 'The Utilisation of African Labour: Cost Trends, Policy and Programme to Meet the Situation', 6 December 1956, pp. 4-11.

44 Ngandu Mutombo, 'Politiques de rémunération, de cotation et de classification des emplois comme facteurs de formation d'une catégorie sociale. Le cas des travailleurs de L'Union Minière du Haut-Katanga, 1947-1967', unpublished $\mathrm{PhD}$ thesis, University of Laval (1996), p. 58. 
Villiers blamed low productivity on an African mentality that remained wedded to 'rural' values and the southern African stereotype of the 'target' worker:

The African, therefore, can and does, follow his traditional way of life in the rural areas.... The knowledge that they can never be destitute while they have the security of their land is partly responsible for the attitude of a high proportion of Africans towards the question of constant employment. They do not work for the economic reasons governing the European. They are generally thriftless and work to earn a target figure to satisfy some present need - the purchase of a bicycle, or sewing machine etc., or for payment of a debt or bride-price. ${ }^{45}$

Achieving improved 'productivity' thus required not only technical changes but also a new mindset, enabling 'the gradual evolution of the individual African's productivity and approach to industrial work. ... a system under which a higher standard of living and progression can be earned ... This would necessitate changing not only employment practices but also the outlook of the African to industrial work'. This would, however, not be easy:

Imagine the dilemma of the African people when they were suddenly catapulted into a western civilisation based on quite opposite assumptions to their own society ... in which the social and economic position of an individual is determined by his earning power ... If this concept is not brought home to the African, years of recurring demands ... and consequent industrial unrest will follow. ${ }^{46}$

De Villiers was, however, pessimistic that such radical improvements could be achieved without increasing wages and conditions 'due to the political and union set-up'. Certainly, by 1964, Rhokana’s African mine workforce still numbered 9,413, though its average length of

ZCCM-IH, 3.8.1C, Utilisation of African Labour Report 1957, W. T. de Villiers, 'The Utilisation of African Labour: Cost Trends, Policy and Programme to Meet the Situation', 6 December 1956, p. 29. The notion of a 'target worker' was a well-established idea in South Africa, which justified the low wages paid to migrant workers by asserting that they worked only to acquire specific goods, so paying them more would only enable them to meet their 'target' earnings in a shorter period: see Desmond Hobart Houghton, The South African Worker (Oxford: Oxford University Press, 1964), pp. 151-2.

46 Ibid., p. 37. 
service had increased to seven years. ${ }^{47}$ By 1959 , it was also acknowledged that rising productivity would not be matched by increased investment, since global demand for copper was stabilising and more competitive mines elsewhere would meet limited additional demand:

Very much less capital will need to be spent between now and 1970. Between 1970 and 1980 it is even possible ... that no new copper mines will be needed on the Copperbelt at all. The pub cannot expect to remain full of bricklayers and carpenters once the building job down the street has been completed.... Thus the possible increases in copper production ... do not necessarily imply proportional increases in the number of men needed. Indeed it appears that much of the production forecasted could be achieved with only a few more men than we have on the Copperbelt now. ${ }^{48}$

The same report concluded: 'There is little prospect that any large industry will soon set itself up on the Copperbelt comparable with the mining industry. 49

Delivering increased productivity, mine companies and their intellectual advisers believed, required the application of Taylorist techniques to the evaluation and design of job descriptions, training and recruitment processes. ${ }^{50}$ The pioneering job evaluation system introduced by UMHK attracted the attention of its counterparts to the south: in 1951 RST officials travelled to Haut-Katanga in the hope that they might be able to introduce such a system in their mines. They approvingly noted not only the sophisticated job evaluation structure but also the provision of education to mineworkers' children. While impressed, they concluded that introducing such a system would be impossible in Northern Rhodesia, where every change to wages and conditions was challenged by an African union with its own view of advancement. ${ }^{51}$

47

' Mine Division, 1928-1991', unpublished PhD thesis, University of the Free State, (2018), p. 101.

48 ZCCM-IH, 3.8.1C, First Report on Regional Survey of Copperbelt, 1959, Special Commissioner for the Western Province, 'A First Report of a Regional

49 Survey of the Copperbelt', 1959, pp. 7-9.

49 Ibid.

50 For the history of Taylorism see Judith A. Merkle, Management and Ideology: The Legacy of the International Scientific Management Movement (Berkeley: University of California Press, 1980).

51 ZCCM-IH, 10.1.8F, 'African Labour: Wages', October 1950-December 1955. 
The company also pioneered the use of intelligence testing of its prospective workers and the children of its workforce, establishing its own Centre de Psychologie et Pédagogie in $1953 .{ }^{52}$ Potential recruits were given psychotechnical tests that theoretically evaluated their capacity for specific areas of employment. David Mupanga, for example, recalls being asked to dismantle a cylinder and put it back together, but also drawing a picture of a village on which one was evaluated on where one's house was pictured in relation to that of the chief. ${ }^{53}$ Mwanza Lukinde had to assemble parts into a cube and work out the most efficient route through town to buy specified products on a fixed budget. ${ }^{54}$ Stéphanie Mumba, who passed her test and was appointed as the head of the laundry at Panda's hospital, recalls that many women who failed such tests were employed in more junior roles, for example as cleaners. ${ }^{55}$ Even in the Northern Rhodesian mines, new employees had to pass aptitude tests by the early 1960s. They were then allocated by the companies to appropriate training and employment. ${ }^{56}$

\section{The Politics of Advancement}

As already noted, there was a disjuncture between the overwhelming focus on advanced workers or évolués in company reports and analysis by social scientists, and their relatively small numbers in the mine workforce. Notwithstanding UMHK's emphasis on skills training, in 1954, 61.4 per cent of the company's total African workforce of 20,762 was on its lowest employment grades numbered 4-7, and 78 per cent on grades 4-9. By 1958, by which time the workforce had expanded to $23,312,54$ per cent were employed on grades $4-7$, but three-quarters were still in grades 4-9.57

In Northern Rhodesia, where a similar structure obtained among African mineworkers, debates over their 'advancement' were racially framed. In 1951, the entire wage bill for the African workforce was

52 UMHKA, 672, Centre de Psychologie et Pédagogie, 1954-5; Lauro, 'The British, the French and Even the Russians Use These Methods'.

53 Interview, David Mupanga, Likasi, 5 June 2018.

54 Interview, Mwanza Lukinde, Likasi, 5 June 2018.

55 Interview, Stéphanie Mumba, Likasi, 6 June 2018.

56 Interviews, Evans Nsabashi, Mufulira, 18 July 2018; Joseph Tumba Mwenzu, Mufulira, 9 August 2018.

57 UMHKA, 658, UMHK MOI Annual Report 1958, p. 64. 
c. $£ 3 \mathrm{~m}$, less than half that paid to the mine companies' approximately 7,000 European workers. ${ }^{58}$ Heated debates over the colour bar led to the 1954 Forster Inquiry into 'advancement'. Of the total African mine workforce of 37,287, 73.7 per cent were in the lowest groups 1 to 3 and were paid between $£ 4$ and $£ 7$ per month. ${ }^{59}$ The highest paid Group 8 African worker earned $£ 19$, and it was these workers, with the potential to advance into European-reserved jobs, that received most attention. But less than one thousand Africans were employed in Groups 7, 8 and the 'Special' category. The minimum European monthly salary was over $£ 99 .{ }^{60}$

Company representatives justified the racial wage gap by claiming that African workers were less adaptable, that their mechanical knowledge was inferior and that their periodic absence during visits to their villages meant they had to be trained afresh on their return to work. Some such limitations were 'inherent and would require to be bred out of the African ... Others, however could be eradicated by training, ${ }^{61}$ Thus, Africans doing the same job as Europeans were seen as less productive and it was therefore justifiable to pay them less for a 'transitional' period: to do otherwise would threaten 'the national economy'. Although the main African Mineworkers' Union (AMWU) (and, for its own reasons, the European union) demanded 'equal pay for equal work', the Mines African Staff Association (MASA), which was subsequently recognised by the Chamber of Mines as the representative body for clerical and senior African staff (see Chapter 4), explained to Forster: 'Although they are all Africans, they do not belong to one class and they do not work under the same conditions.

58 Ibid., p. 25.

59 ZCCM-IH, 3.8.2E, Forster Board of Inquiry, Afr Advancement, September 1954, 'Report of the Board of Inquiry Appointed to Inquire into The Advancement of Africans in the Copper Mining Industry in Northern Rhodesia', p. 13, p. 48.

60 ZCCM-IH, 3.8.2E, Forster Board of Inquiry, Afr Advancement, September 1954, 'Report of the Board of Inquiry Appointed to Inquire into The Advancement of Africans in the Copper Mining Industry in Northern Rhodesia', 13-14. See also Epstein, Politics in an Urban African Community, pp. 244-5.

61 ZCCM-IH, 3.8.2E, Forster Board of Inquiry, Afr Advancement, September 1954, 'Report of the Board of Inquiry Appointed to Inquire into The Advancement of Africans in the Copper Mining Industry in Northern Rhodesia', pp. 20-1. 
Therefore they are not on the same level'. ${ }^{62}$ Partially accepting the logic of the mine companies' argument, MASA argued that Africans should be paid 75 per cent of the European rate for the job. ${ }^{63}$ Despite the continuing exclusion of Africans from training opportunities such as apprenticeships, Forster concluded that Africans were partly to blame for their low pay:

until Africans in general fully grasp the vital relationship between ... work on the one hand and advancement on the other and that the former must precede and justify the latter and until they behave accordingly ... the gap will, for the main majority of Africans, remain unbridgeable. ... there will be a proportion of exceptional Africans fitted for advancement, at first into work the value of which truly lies in the gap between the two wage structures and later into work which truly lies in the European wage structure. ${ }^{64}$

Significant improvements were made to Northern Rhodesian African wages and conditions in the subsequent decade, often in response to organised industrial action: a pension scheme was introduced in 1954. Yet mine companies continued to justify slow African advancement in evolutionary terms. Ernest Oppenheimer, Chairman of AAC's Nchanga Consolidated Copper Mines (NCCM), declared in March 1955:

The keynote of African advancement is - again - responsibility; this does not mean merely the acquisition of increased operative skill, but embodies as a fundamental concept the development of a sense of judgment and a measure of self-discipline. These are mental attributes which are not acquired overnight ... and so far as the African is concerned, must be achieved against an unfavourable background. Unlike the European, the African is lacking in industrial tradition - his whole past is bound up with the soil - and ... it will be a slow and evolutionary process. ${ }^{65}$

Under the Advancement agreement signed that year, 185 Africans employed by NCCM were promoted to jobs previously carried out

62 ZCCM-IH, 3.8.2E, Forster Board of Inquiry, Afr Advancement, September 1954, 'Report of the Board of Inquiry Appointed to Inquire into The Advancement of Africans in the Copper Mining Industry in Northern Rhodesia', p. 26.

63 ZCCM-IH, 3.8.2E, Forster Board of Inquiry, Afr Advancement, September 1954, MASA Submission to the Forster Board of Inquiry, p. 3.

64 Ibid., p. 18.

65 ZCCM-IH, NCCM Annual Report 1955, Chairman's Review, p. 6-7. 
by Europeans. ${ }^{66}$ By 1959 the three lowest employment groups still accounted for 65 per cent of the workforce. Only 4 per cent of Africans were employed in the most advanced categories. ${ }^{67}$ Powdermaker found that, although Northern Rhodesian mineworkers experienced a real terms increase in their 'income' - their wages, together with housing and social provision - between 1950 and 1960, they continued to perceive themselves as badly off, compared with the observable standard of living of the Europeans who supervised their work and to whose jobs they aspired. ${ }^{68}$ Despite strenuous efforts at the 'Zambianisation' of senior jobs in the 1960s and 1970s (Chapter 6), many thousands of whites continued to occupy most of the senior positions (and earn many times more money) until the late 1970s.

It is impossible to directly compare the wages of African mineworkers on either side of the border: as a general rule, cash wages were higher in Northern Rhodesia than in Haut-Katanga for the same mine job, but UMHK provided a greater proportion of compensation in non-cash form, for example food 'rations', housing and other benefits. This difference was significant however, since UMHK's use of non-cash wages meant that, alongside its lack of African union representation, it avoided direct engagement with its workforce over the value of its labour. Dibwe dia Mwembu notes that UMHK sought to manage the cost burden by providing different forms of cash and in-kind remuneration to each category of African worker: low-skilled workers received only a small cash wage with all other provisions in-kind; 'middle' workers received higher cash wages that now included their food costs; and more specialised workers under the 'global' system were paid entirely in cash. ${ }^{69}$ In these and other ways mine companies sought to avoid general improvements in wages and conditions across the workforce, and had a vested interest in promoting divisions among their workers that were justified through a meritocratic discourse. The UMHK's managers constantly likened the company to a family headed by benevolent patricians, but this was a metaphor entirely compatible with hierarchy and inequality.

66 ZCCM-IH, NCCM Annual Report 1956, p. 5.

67 Powdermaker, Copper Town, p. $89 . \quad{ }^{68}$ Powdermaker, Copper Town, p. 91.

69 Dibwe, Histoire des Conditions de Vie, p. 50. A detailed analysis of UMHK salary structures is provided in Ngandu Mutombo, 'Politiques de rémuneration', pp. 229-41. 


\section{Unease, Inequality and Influx Control, 1957-1964}

Even during its great economic boom, therefore, the Copperbelt was never a region of generalised development or rising living standards. Capital outflow and mining's skewed relationship with the wider economy limited the creation of jobs and businesses. The highly uneven distribution of wages, housing and other rewards intersected with racial segregation and profoundly unequal power relationships between women and men, between skilled and unskilled mineworkers, mineworkers and other wage earners, and wage earners and the wider non-waged population - to create tension, conflict and social unrest. Northern Rhodesia's Copperbelt towns were thought by the authorities to have very high crime levels: in 1958, the Mufulira Native Court handled 3,524 cases for a population of c.30,000 adults. Half of these offences involved 'unauthorised residence' in municipal or mine township areas, the second highest category involving identity certificate and registration offences, with other crimes including house burglary, theft of bicycles and an increasing number of driving offences. Of particular concern was the rising number of crimes committed by African adolescents, up from 104 in 1957 to 123 in 1958, evidence for the authorities of the quintessential Western social malaise of the 1950s, growing 'juvenile delinquency'. ${ }^{70}$ Luise White details how rumours - about the kidnapping of children, poisonings and witchcraft of different kinds - circulated through tense and distrustful Copperbelt societies. Far from being a manifestation of rural superstition, such rumours reflected residents' experiences of an economic and social order that was permanently in flux. ${ }^{71}$ In Mufulira six cases were brought under the Witchcraft Ordinance in 1956, four of accusing others of practising witchcraft and two of claiming supernatural powers. ${ }^{72}$ This was also a region of increasing political unrest and sometimes violence, as will be discussed in Chapter 4.

These tensions were heightened by a brief but punishing recession of 1957-8, when the global copper price fell dramatically and the assumptions underlying Copperbelt growth were severely tested. The 1958

70 NAZ, WP 1/2/45, Annual Report African Affairs Ndola. 1957-61, ‘Annual Report of African Affairs, Mufulira, 1958', Ch. 8, np.

71 White, Speaking with Vampires, pp. 269-306.

72 NAZ, WP 1/2/45, Annual Report African Affairs Ndola. 1957-61, 'Annual Report of African Affairs, Mufulira, 1957', p. 17. 
Provincial Council meeting heard that 'Katanga, despite the relatively significant development of its secondary industry, remains very sensitive to the fluctuation in the prices of raw materials, the export of which represents for the Colony, one of the most important sources of income'. ${ }^{73}$ Unemployment manifested itself in Katanga's main towns, though the Provincial Council agreed that it could not be addressed as it was in Europe:

the problem of unemployment is not comparable with that in Belgium, since the economic system and structure of Congo was different.... the solution of the problem does not consist in creating an unemployment fund, the establishment of which would be contrary to the interests of the rural population, but in remedying the situation, which is likely to become more and more serious, by finding an occupation for these unemployed. ${ }^{74}$

Programmes of public works were created to absorb the unemployed, who numbered c.3,500 in Elisabethville and 1,500-2,000 in Jadotville (later Likasi). Other actions included:

- rigorous measures to halt the influx into the towns;

- continuing the policy of ejecting from the towns in favour of return to the land;

- reduce the existing contrast between the living conditions in the towns and the rural milieu by raising the incomes of the rural Africans;

- inculcate in the young a love of manual labour. ${ }^{75}$

Katanga strictly controlled African movement, something that Northern Rhodesian officials desired to emulate. A meeting there on urban African unemployment in January 1958 proposed 'a comprehensive system of identification, including full finger-printing ... (on the Belgian Congo pattern)'. ${ }^{76}$ While official Katangese discourse tended towards optimism, identifying solutions in indigenous agricultural and peri-urban development, Northern Rhodesian officials worried about the negative effects of unemployment in both villages and towns. They called for

73 BAA, 36(3), KPC, Session Générale, Opening Statement, Governor Paelinck, September 1958.

74 BAA, 36(4), KPC, Session Générale, Commission Prépatoire No. 1, Séance, 2 September 1958, p. 1.

75 Ibid., pp. 1-2.

76 ZCCM-IH, 16.3.8C, Mine Township Mgt Board - Health Officers, July 1929November 1979, 'Chamber of Mines Mtg, Companies and Lab Commissioners, 24/1/58', 'to consider problems of African unemployment in urban areas', p. 1. 
development planning, as pioneered in Congo, but were more pessimistic that this would translate into an effective policy. C. Fourie, a senior government officer with responsibility for African affairs, stressed the need for a territory-wide approach to 'influx control' that would focus on 'the social and economic development of rural areas parallel with urban areas, to enable them to compete with the attraction of the towns'. ${ }^{77}$

During the recession, employers searched in vain for the right kind of workers, for example in Kitwe in 1958:

Africans are offering for work in great numbers. At the big mines, 600 to 700 Africans appear when men are being taken on. Really good labourers and domestic servants are in demand and in short supply. African drivers, building trade workers and clerks of poor quality abound and cannot get jobs. ${ }^{78}$

A 1958 conference of local government officials resolved that it was necessary to tackle urban unemployment in rural areas:

the best method of dealing with the problem .... was to start at the source, that is, the village itself and the Chief in charge, and that no African should be allowed to leave his own area unless the Chief had been advised that there was room for him in the peri-urban areas, or if there was a shortage of labour ... then Africans could be allowed to enter those areas. ${ }^{79}$

The tripartite African Labour Advisory Board heard from companies and unions on the issue: 'The three Employee Representatives agreed that the problem of work-shy parasites in employment centres was a big one.... ultimately the development of rural areas would be the best solution but [it was] agreed that this would take a considerable time to have its effect'. African trade union representatives expressed their personal familiarity with the problem: 'Each referred to his personal experience of having to accommodate and feed "brothers" who came to the Copperbelt and were extremely difficult to dislodge. ${ }^{80}$

77 NAZ, WP 1/11/2, African Social and Political Development in Urban Areas, 1951-6, C. Fourie, Officer for African Affairs to District Commissioner, Kitwe, 23 December 1955.

78 NAZ, WP 1/2/53, Labour: Dept of Labour monthly reports, 1958-60, Department of Labour Report for February 1959, p. 7.

79 NAZ, WP 1/2/61, Report of Director of African Affairs Chingola 1959, Decisions taken at 12 th Annual Conference, Municipal Association of Northern Rhodesia, 13-15 May 1959, p. 1.

80 ZCCMA, 16.3.7A, 'African Advisory Board, Feb 1951-Jan 1958', meeting 23 January 1957, pp. 1-2. 
Trade union backing was thought vital for action against the 'loafer' problem: by January 1959 c.6,000 African men had been 'repatriated' to their rural areas of origin, reducing the number of unemployed in Northern Rhodesian Copperbelt towns to c.5,000. It was, however, acknowledged that nothing could prevent them from returning. ${ }^{81}$

Although a higher copper price enabled the economy to bounce back by the start of the 1960s, this was essentially a jobless recovery. From this point on urban unemployment was consistently highlighted in government reports both in Northern Rhodesia and Katanga. In Luanshya in 1959, '[r]ecovery from the recession has been very slow ... There has been little expansion in secondary industry and African unemployment remains at a high level. When there is wind of work available the long queues at the local labour exchange are ample testimony'. ${ }^{82}$ In 1960 in Mufulira, 'the supply of labour exceeded the demand, and as activity slowed down towards the end of the year, so the position deteriorated and labour forces were reduced, with a resultant increase in the number of unemployed'. ${ }^{83}$ In Katanga, the 1959 Provincial Council meeting heard that unemployment had risen in Elisabethville to 7,142 and in Jadotville to 1,284. Katanga's employment figure had fallen from its 1954 peak of 197,443 to 160,776 in 1958 , while the 'extra-customary' population had risen from 509,327 to $570,079 .{ }^{84}$ There was growing alarm at youth unemployment: 'The youth of our towns is one of our principal preoccupations. We are faced with a growing number, year on year, of young adolescent idlers who neither go to school nor are in work. It is estimated that there are at least 3,000 in Elisabethville at the moment'. There was then a need to 'create new sites in the periphery to encourage the return to the land of a large part of this workforce that will never find employment in existing businesses'. ${ }^{85}$ Indeed, right up to Congolese independence,

81 ZCCMA, 16.3.8C, Luanshya Mine Township Mgt Board - Health Officers, July 1929-November 1979, meeting between company representatives and Senior Provincial Commissioner, 17 January 1959, p. 2.

82 NAZ, WP 1/2/43, African Affairs Annual Report, Luanshya, 1957-60, 'Luanshya African Affairs Annual Report', 1959, np.

83 NAZ, WP 1/2/66, DCs reports 1960, 'Annual Report on African Affairs, Mufulira', p. 12.

84 BAA, 37(2), KPC, Session Extraordinaire, 1959, Allocution D’Ouverture du V. GG Schoeller, np.

85 BAA 37(1), KPC, Session Extraordinaire, 1959, Allocution D’Ouverture du Commissaire Provincial M. Thilmany, pp. 26-7. 
the CEPSI-linked initiative FULREAC (Fondation de L'Universite de Liège pour les Recherches Scientifiques au Congo Belge et au Ruanda-Urundi) continued agricultural activities in Mangombo, near Jadotville, one of a number of 'projets de decongestion des grands centres urbains. ${ }^{86}$

A census conducted in May-June 1963 revealed that in Northern Rhodesia there were 255,910 African men in paid employment, 275,570 who were self-employed and 74,480 'seeking paid employment'. ${ }^{87}$ Later that year a report identified 'unemployment' and 'the drift to the towns' as two of the three 'tremendous problems' facing Northern Rhodesia, 'bearing in mind that all those at present out of work in Kitwe will never be absorbed no matter what industrial expansion takes place'. ${ }^{88}$ Of the city's over-eighteen male population of 35,000, 8,936 were employed in mining, 20,000 in other jobs and 6,000 were unemployed. ${ }^{89}$ In Mufulira's municipal area there were, in 1961, twenty-eight licensed African businesses, compared with none in $1956 .^{90}$ African entrepreneurship was, however, restricted by a lack of access to credit and by European and Asian domination of retail, and what existed was negatively perceived: 'The number of Africans hawking vegetables in the streets has increased considerably. They cannot make a living this way and are having an adverse effect on the legitimate marketeers'. ${ }^{91}$ The prospects were not promising. In Mufulira, where the mine employed c.9,000 workers, an existing population of c.66,000 was forecast to rise to 97,870 by 1971 , in a period when 'there is unlikely to be an upsurge in employment in the established mining industry'. ${ }^{92}$ GG Schoeller, pp. 21-2.

87 NAZ, LSS 1/22/30, Labour Consultative Committee, 1962-4, LCC Note for Members, meeting 27 February 1964.

88 NAZ, WP 1/2/74, Native Affairs, Annual Reports, 1963, 'Native Affairs Annual Report, Kitwe, 1963', p. 1.

89 Ibid., p. 5.

90 NAZ, WP 1/2/45, Annual Report African Affairs, Ndola, 1957-61, 'Annual Report of African Affairs, Mufulira, 1961', p. 13.

91 NAZ, WP 1/2/74, Native Affairs, Annual Reports, 1963, 'Native Affairs Annual Report, Kitwe, 1963', pp. 8-11.

92 NAZ, WP 1/2/45, Annual Report African Affairs, Ndola, 1957-61, 'Annual Report of African Affairs, Mufulira, 1961', p. 8; ZCCMA-IH, Copperbelt Development Plan, 1965, p. 1.66. 


\section{Uneven Development: Capital and Labour After Independence}

Ostensibly, national independence created the possibility of breaking from the colonial extractive model on which the Copperbelt had been built. Zambian independence fuelled confidence about future economic development and the government signalled that it would invest in the economy and create a large number of jobs. A 1965 Copperbelt Development Plan confidently stated:

With a settled National Government the Copperbelt ... can be expected to attract new industry and commerce and contribute, for many years, the major finance required to enable physical and social development to spread to the backward regions of the territory. ${ }^{93}$

The region's disadvantages for secondary industry, however, remained:

The entrepreneur is being encouraged to develop within the boundaries of the territory for a new and expanding market, and the Copperbelt region, with its larger concentration of population and growing reserve of skilled labour, is proving an attractive area ... for production of consumer goods. The Copperbelt is not, however, a natural centre for secondary industry, as long transport hauls are necessary to reach export markets, and, therefore, it is unlikely that any major concentration, outside the mining industry, will result. $^{94}$

The post-independence governments of Zambia and DR Congo were fully aware of the difficulty of developing their economies beyond the mining industry. Early development plans warned about continuing dependency on mining and stressed the need for diversification. In the short term however, mineral production was expanded as the only way to raise revenue to fund a programme of diversification. ${ }^{95}$ Zambian copper production rose accordingly, from 568,000 tonnes in 1963 to 720,000 tonnes in 1969 . There was also a significant increase in African mine employment, from 36,946 in 1963 to 43,500 in 1969 , with many new jobs coming not in production but in processing and areas such as social services and education. ${ }^{96}$ In Congo/Zaire, President

93 ZCCM-IH, Copperbelt Development Plan 1965, p. 1.5. 94 Ibid., p. 1.99.

95 United Nations/Economic Commission for Africa/Food \& Agriculture Organisation, Economic Survey Mission on the Economic Development of Zambia (Ndola: United Nations/Economic Commission for Africa/Food \& Agriculture Organisation 1964).

96 Daniel, Africanisation, Nationalisation and Inequality, p. 107; ZCCM-IH, Zambia Mining Yearbooks, 1965-8. 
Mobutu drove up mine production in the late 1960s despite the risk of over-supply to the global market. Copper production, which fell from 300,000 tonnes in 1960 to a low of 269,000 tonnes in 1963 during the secessionist conflict, rose to 406,000 tonnes in 1971. Gécamines employed 24,586 workers in 1971, including 1,007 women. Of its 2,129 senior employees, however, only 720 were African. ${ }^{97}$

The redirection of mine tax revenue to independent governments created the potential for investment in non-mining sectors, but this did not overcome an export dependency on copper and cobalt mining, with its limited linkages to the local economy. Development policy instead directed mine tax revenue into state-directed or state-owned industries and substantial infrastructural investment to support them. In the late 1960s, Zambia's Industrial Development Corporation (Indeco) oversaw nationalised and semi-nationalised companies outside the mining industry. ${ }^{98}$ But such initiatives were shaped by political rather than economic considerations: in Zambia, key industrial projects were distributed across the country rather than being concentrated in the Copperbelt. At a local level, '[n]o large scale industrial expansion is foreseen at Mufulira and its present light industrial service area should be adequate. ${ }^{99}$

In newly independent Congo, the dislocating effects of the post-1960 crisis initially prevented meaningful development activity and led to the collapse of much of the rural health and educational provision built up in the late colonial period. The already fragmented 'national' economy was further disrupted by the Katangese secession. ${ }^{100}$ Peemans characterised Congo as having industries but not industrialisation: it had developed an internal market for consumer goods and Haut-Katanga had industries that served the needs of mining, but the economy was oriented to export earnings rather than integrated national development. Although mining taxes accrued to the growing state and funded development programmes, mine revenue continued to flow out as dividend payments and was not invested in Congo's wider economy, which lacked an effective local banking system that could have

97 Gécamines Annual Report, 1971, p. 13 and p. 30.

98 Andrew Sardanis, Africa, Another Side of the Coin: Northern Rhodesia's Final Years and Zambia's Nationhood (London: Bloomsbury, 2003), pp. 164-89.

99 ZCCM-IH, Copperbelt Development Policy, 1965, p. 147.

100 Peemans, 'Social and Economic Development of Zaire', pp. 155-6. 
provided credit to entrepreneurs. ${ }^{101}$ Under Mobutu, however, state control over the economy and society was consolidated and then considerably strengthened. In the late 1960s, the governments of both countries nationalised their mining industries, a topic explored in Chapter 6.

There was a post-independence expansion of education of all kinds, nationally and in the Copperbelt in particular: an expansion of primary and secondary school places, but also of vocational training to address the massive skills gap that was, especially in Zambia, a legacy of the colour bar. ${ }^{102}$ In Haut-Katanga the loss of many European educators, particularly in Catholic schools, did not substantially undermine UMHK-run primary schools, which workers' children could attend for free. Schemes such as the Zambia Youth Service provided training in areas such as carpentry, bricklaying and farming. ${ }^{103}$ In Luanshya in 1968, a Youth Development Scheme run by the Mine Townships Management Board provided training in carpentry, bricklaying, welding, driving, motor repair and light engineering to at least 100 young people. ${ }^{104}$ As well as primary schooling, mine companies provided adult literacy education; staff training for skilled work; apprenticeship schemes for aspirant 'advanced' Africans; and medical training for prospective hospital and clinic workers. ${ }^{105}$

Mine companies also gave preferential access to the children of existing employees in filling vacancies, a policy that continued into the 1980s. ${ }^{106}$ The UMHK built on its 'scientific' recruitment procedures in its schools to identify and shape the education of its future workforce. The company's schools were widely seen as better run and/or more disciplined than state schools, attracting the best teachers with higher wages. ${ }^{107}$ Although Zambian mines lacked equivalent

\footnotetext{
101 Ibid., pp. 149-50.

102 NAZ, WP 1/2/45, Annual Report African Affairs, Ndola, 1957-61, Annual Report of African Affairs, Mufulira', 1961, p. 17.

103 NAZ, WP 1/2/75, Native Affairs Annual Reports 1963-5, Department of Labour, Annual Report 1964, p. 2.

104 NAZ, LSS 1/22/24, Annual Reports, Labour Officer, Luanshya, 1947-67, LO S. D. Sacika, 13 January 1968.

105 NAZ, WP 1/2/74, Native Affairs Annual Reports, 1963, 'Kitwe District Annual Report on African Affairs', p. 14; NAZ, WP 1/2/75, Native Affairs Annual Reports 1963-5, Labour Department Annual Report 1964, p. 6.

106 Interview, Leonard Nkhuwa, Mufulira, 30 July 2018.

107 Interviews: Mwanza Lukinde; Jérôme Kipili Mulunda, Likasi, 4 June 2018.
} 
control over education, they ran an annual recruitment round of the minority of students who could afford to complete secondary school in the 1960s and 1970s. ${ }^{108}$ For the educated children of mineworkers on both sides of the border, the demand for increasingly skilled African workers in the first decade of independence represented a one-off opportunity for social advancement. Levy Chushi, whose father worked for the Mufulira mine, started work aged nineteen as an underground lasher in 1965 . He received training in mechanics, studied briefly at the new University of Zambia (UNZA) and, after successive promotions, acquired the senior position of Mine Captain in $1987 .{ }^{109}$ Owess Nkhama, whose Malawian father was a rockbreaker in the 1920s and 1930s, became the leader of a mine social club in 1959, studied youth management and sociology under company auspices in the 1960s and was later a senior personnel manager. ${ }^{110}$ Sara Léontine Bulanda became a Gécamines employee and managed the Panda canteen where her mineworker father had once eaten. ${ }^{111}$ In lieu of other opportunities, mine work remained one of the most attractive options for Copperbelt residents. While Zambian workers received cash-only wages after independence, the 'final' abolition of food rations in UMHK in 1962 was suddenly and permanently reversed in 1964 when, amidst soaring food prices, the company re-established indirect food supplies in the form of subsidised retail sales and canteen meals. ${ }^{112}$ This measure is widely recalled as an act of company generosity that showed it cared for its workers.

Despite the Copperbelt's lack of sustained development, it continued to attract tens of thousands of new migrants, motivated as much by the continued poverty of rural villages as the availability of employment opportunities. Many new arrivals and some of those born in town found ways of earning a living outside paid employment. Morris Chimfutumba, born in Mufulira in 1930, worked first as a petrol attendant and then as a company salesman, before buying a European-owned bottle store and selling fish he brought from

108 Simon Bwalya, whose father was an unskilled mine workman, was recruited directly from school in 1968: interview, Mufulira, 9 July 2018. See also interview, Cossam Chali, Mufulira, 21 July 2018.

109 Interview, Levy Chushi, Mufulira, 11 July 2018.

110 Interview, Owess Nkhama, Mufulira, 8 August 2018.

111 Interview, Sara Léontine Bulanda, Likasi, 6 June 2018.

112 Dibwe dia Mwembu, Histoire des Conditions de Vie, p. 60. 
Luapula Province. ${ }^{113}$ Thomas Kalimanshi, whose parents migrated from Katanga and whose father became a bricklayer and carpenter in Mufulira, started a taxi business in 1968 that became a highly successful transportation company, partly by providing transport services to ZCCM. ${ }^{114}$ Michel wa pa Bowa established a subcontracting company providing cleaning and refuse services to Gécamines' hospitals, schools and camps, aided by his brother's senior position in the company. ${ }^{115}$

For many, a mine company job remained the gold standard, delivering as it did not only a salary and a secure job but also access to housing, schooling for children and other social services. Simon Kampamba, who worked for a series of small companies as a carpenter, applied unsuccessfully for a job with the mines on three occasions in the 1970s, hoping to benefit from its superior retirement package. ${ }^{116}$ But for others, mining was a dangerous and low-status job to be avoided. Matthias Mutupa's mineworker father promised to find him a job in the mines, but he instead became first a salesman and then a delivery driver for the Olympic milling company. ${ }^{117}$ Evans Nsabashi chose to become a teacher, earning less than a mineworker, because teaching was less physically demanding. ${ }^{118}$ One's employment increasingly depended on one's education or training, which partly reflected ability and upbringing but also fortune - the death of a parent or relative might mean school fees could no longer be paid or that one had to leave education to provide for the family. ${ }^{119}$ Copperbelt towns were then places, if not of development along Western lines, then of possibility, whose residents envisaged progress and self-realisation in diverse ways, both within and beyond the constraints of formal employment. Kabwika Ntanda Kadisabula, whose mineworker father fled to his native Kasai with his young family during the secession, went on to work for the Banque Commerciale du Congo. In the mid-1970s he ran a petrol station, living and working in Kikula, and used this as

113 Morris Chimfutumba interview.

114 Interview, Thomas Kalimanshi, Mufulira, 30 July 2018.

115 Interview, Michel Mudimba wa pa Bowa, Likasi, 18 June 2018.

116 Interview, Simon Kampamba, Mufulira, 16 July 2018.

117 Interview, Matthias Mutupa, Mufulira, 19 July 2018.

118 Evans Nsabashi interview.

119 Simon Bwalya interview; interview, Dewys Mulenga, Mufulira, 20 July 2018; interview, François Kake, Likasi, 11 June 2018. 
a springboard to become a local MP. ${ }^{120}$ Musale Kibombo, whose father was also a mineworker, became a domestic worker for Europeans, a job he held throughout his entire working life. Rejecting the notion that this was a subservient position, Kibombo argues:

it is rather those who worked at Gécamines who did not have much independence, since they were interned in Gécamines homes and were forced to start work at six in the morning and finished late in the evening. I, a servant, am in the same plot as my boss and my house is next door. In the morning, before the boss left, he left a programme in the kitchen [and then] I am the manager of the house, I had all the keys and I watched everything. ... in town, there were civilised people. ${ }^{121}$

Even some successful mineworkers observed that, once trained and employed by ZCCM or Gécamines for specific jobs, they had no other option for local employment - there was nowhere else to go. But town was for many urban migrants a place not associated primarily with formal employment, which was in any case increasingly limited to those with schooling. Indeed, the education of one's children, who might by such means better themselves and care for you in later life, was arguably a greater motive for urban residence than salaried employment. ${ }^{122}$

\section{Conclusion}

For government officials in particular, the Copperbelt boom was as much of a problem as it was a success: it brought to the region a growing population that was increasingly difficult to control and manage. Mine towns, designed initially for workers and then their immediate families, drew in a far larger population, prompted by rural poverty and the better life that could be achieved by a range of social and economic activities that were only indirectly related to the mining industry. This was in a context where employment opportunities were few and industrial development remained limited.

It must, however, be acknowledged that forecasts of stagnant or declining mine employment proved wide of the mark: both Zambian and Congolese/Zairian mine companies steadily increased their

120 Interview, Kabwika Ntanda Kadisabula, Likasi, 5 June 2018.

121 Interview, Musale Kibombo, Likasi, 21 June 2018.

122 See, for example, Maxwell Mukupa interview. 
workforce in the independence period. This partly reflected governmental pressure to increase production for the purposes of state revenue, against the advice of company management. The mines did not, however, become the basis of a more fully fledged industrial system: the independent governments of both countries, for different reasons, tended to direct new industries away from the Copperbelt (see Chapter 6). In any case, the growth of the region's population continued unabated and regardless of the availability of formal sector jobs: with the removal of colonial controls and in a context of continued rural stagnation, migration to the Copperbelt towns sharply accelerated after independence. Efforts to manage this population, as we will see in the next chapter, involved not only physical controls on their movement and settlement but also constant surveillance of the activities of legal residents. This was in turn underpinned by a highly moralistic discourse about those who did and did not deserve a place in the town, framed in the characteristically modernist terms of the Copperbelt imaginary. 